\title{
Analisis Putusan PTUN NO. 7/G/LH/2019/PTUN.BNA antara Walhi Melawan Gubernur Aceh atas Penerbitan Izin Pinjam Pakai Kawasan Hutan untuk Pembangunan PLTA Tampur \\ Antonius Aditantyo Nugroho ${ }^{1}$
}

\section{Pendahuluan}

Pada 19 Agustus 2019, Majelis Hakim Pengadilan Tata Usaha Negara (PTUN) Banda Aceh mengabulkan gugatan yang diajukan oleh Yayasan Wahana Lingkungan Hidup Indonesia (Walhi) melawan Gubernur Aceh atas penerbitan Keputusan Gubernur Aceh No. 522.51/ DPMPTSP/1499/IPPKH/2017 tanggal 9 Juni 2017 tentang Pemberian Izin Pinjam Pakai Kawasan Hutan Dalam Rangka Pembangunan Pembangkit Listrik Tenaga Air Tampur-I (443 MW) Seluas \pm 4.407 ha atas nama PT Kamirzu di Kabupaten Gayo Lues, Kabupaten Aceh Tamiang, dan Kabupaten Aceh Timur Provinsi Aceh (selanjutnya disebut Objek Sengketa). Setelah melalui masa persidangan selama 5 (lima) bulan sejak gugatan diajukan tanggal 11 Maret 2019, Majelis Hakim PTUN Banda Aceh memutuskan bahwa Objek Sengketa tidak sah, dan mewajibkan Tergugat untuk mencabut Objek Sengketa.
Perhatian pegiat lingkungan hidup atas Desa Lesten-Pining, Kabupaten Gayo Lues yang diatur dalam Objek Sengketa rupanya telah muncul sejak tahun 2016 hingga 2017. Pada September 2016, Pemerintah Aceh mulai membangun jalan akses dari Kecamatan Pining ke wilayah Desa Lesten yang selama ini terisolasi. ${ }^{2}$ Karena khawatir perambah semakin mudah masuk dan merusak Kawasan Ekosistem Leuser yang menjadi lokasi Desa Lesten-Pining, pegiat lingkungan hidup menyarankan agar masyarakat Desa Lesten direlokasi dan tidak perlu dilakukan pembangunan jalan pada kawasan tersebut. ${ }^{3}$ Namun setelah pembangunan jalan tetap dilaksanakan dan selesai dilakukan, Pemerintah Aceh justru menyetujui pembangunan PLTA Tampur, sehingga masyarakat Desa Lesten harus direlokasi karena Desa Lesten akan ditenggelamkan. ${ }^{4}$ Patut dicurigai bahwa alasan pembangunan jalan untuk membebaskan masyarakat Desa Lesten dari

\footnotetext{
${ }^{1}$ Penulis peneliti pada Yayasan Pengembangan Hukum Lingkungan Indonesia/Indonesian Center for Environmental Law (ICEL).

2 "Lesten Tidak Lagi Terisolir", Serambinews.com, 4 September 2016, https://aceh.tribunnews. com/2016/09/04/lesten-tidak-lagi-terisolir, diakses 25 Oktober 2019.

${ }^{3}$ Junaidi Hanafiah, "Desa Lesten Akan Ditenggelamkan Demi Alasan PLTA Tampur", Mongabay, 21 Agustus 2019, https://www.mongabay.co.id/2019/08/21/desa-lesten-akan-ditenggelamkandemi-alasan-plta-tampur/, diakses 25 Oktober 2019.

4 "Dampak Pembangunan PLTA, Seluruh Warga Lesten Direlokasi", Teropong Aceh, 7 Oktober 2016, http://teropongaceh.com/dampak-pembangunan-plta-seluruh-warga-lesten-direlokasi/ , diakses 25 Oktober 2019.
} 
Analisis Putusan PTUN NO. 7/G/LH/2019/PTUN.BNA antara Walhi Melawan Gubernur Aceh atas Penerbitan Izin Pinjam Pakai Kawasan Hutan untuk Pembangunan PLTA Tampur

isolasi hanyalah kedok bagi Pemerintah Aceh untuk menyediakan akses bagi masuknya pembangunan PLTA di Kawasan Ekosistem Leuser.

Atas latar belakang tersebut, putusan Majelis Hakim PTUN Banda Aceh dianggap mampu mengembalikan rasa keadilan baik terhadap masyarakat Desa Lesten maupun terhadap kelestarian Kawasan Ekosistem Leuser. Adapun Majelis Hakim mengabulkan gugatan Penggugat untuk seluruhnya atas dasar pertimbangan bahwa Gubernur Aceh in casu Tergugat tidak berwenang untuk menerbitkan Objek Sengketa, sehingga penerbitan Objek Sengketa tersebut telah bertentangan dengan asas kepastian hukum dan asas tidak menyalahgunakan kewenangan. Maka perdebatan yang tersorot dalam putusan adalah terkait dengan kewenangan penerbitan Objek Sengketa antara pemerintah pusat dengan pemerintah daerah otonomi khusus Aceh, dan pertimbangan Majelis Hakim belum menyentuh substansi pokok sengketa yang lain. Walau demikian, putusan ini menjadi pembelajaran yang baik terutama di tengah upaya pemerintah mengejar target rasio elektrifikasi ${ }^{5}$ dan pemenuhan kebutuhan listrik ${ }^{6}$, yaitu agar setiap pembangunan pembangkit tenaga listrik tetap memperhatikan ketentuan atas perizinan sebagai instrumen pencegahan kerusakan lingkungan hidup $^{7}$ sebagaimana diatur dalam peraturan perundang-undangan yang berlaku.

\section{Kasus Posisi}

Berikut merupakan kasus posisi yang disusun berdasarkan peristiwa hukum yang dicantumkan dalam Putusan, yaitu dimulai dari proses penerbitan Objek Sengketa, upaya administrasi yang telah ditempuh oleh Penggugat, masuknya gugatan terhadap Objek Sengketa, dan proses persidangan hingga putusan Majelis Hakim:

1. Tanggal 9 Juni 2017, Gubernur Aceh menerbitkan Keputusan Gubernur No. 522.51/DPMPTSP/1499/IPPKH/2017 tentang Pemberian Izin Pinjam Pakai Kawasan Hutan Dalam Rangka Pembangunan Pembangkit Listrik Tenaga Air Tampur-I (443 MW) Seluas \pm 4.407 Ha atas nama PT KAMIRZU di Kabupaten Gayo Lues, Kabupaten Aceh Tamiang, dan Kabupaten Aceh Timur Provinsi Aceh ("Objek Sengketa”).

\footnotetext{
${ }^{5}$ Ghani Nurcahyadi, "Mengejar Rasio Elektrifikasi 96\%", Media Indonesia, 27 Oktober 2017, https://mediaindonesia.com/read/detail/129230-mengejar-rasio-elektrifikasi-96.html, diakses 30 Oktober 2019.

${ }^{6}$ Gemal A.N. Panggabean, "Hingga 2026, Aceh Butuh Tambahan Pembangkit Listrik 2.837 MW", Bisnis.com, 9 November 2017, https://ekonomi.bisnis.com/read/20171109/44/707692/hingga2026-aceh-butuh-tambahan-pembangkit-listrik-2.837-mw, diakses 30 Oktober 2019.

${ }^{7}$ Henri Subagiyo et. al., Anotasi Undang-Undang Nomor 32 Tahun 2009 tentang Perlindungan dan Pengelolaan Lingkungan Hidup, (Jakarta: Cano Digital Copy and Printing, 2014), hlm. 135.
} 
a. Berdasarkan Konsiderans "Memperhatikan" dalam Objek Sengketa, turut disebutkan Surat Kepala Dinas Lingkungan Hidup dan Kehutanan Aceh No. 522.12/2700-IV Tanggal 9 Juni 2017 perihal Rekomendasi Izin Pinjam Pakai Kawasan Hutan Pembangunan Pembangkit Listrik Tenaga Air (PLTA) Tampur-I.

b. Dari 3 (tiga) Kabupaten yang menjadi wilayah Objek Sengketa, Kabupaten Gayo Lues telah menyampaikan rekomendasi/dukungannya melalui Surat Bupati Gayo Lues No. 050/1079/2016 Tanggal 27 September 2016 perihal Dukungan Pembangunan Pembangkit Listrik Tenaga Air, dan Kabupaten Aceh Tamiang melalui Surat Bupati Aceh Tamiang No. 671/6288 Tanggal 10 Oktober 2016 Perihal Dukungan Pembangunan PTLA Tampur. Sementara itu belum ditemukan dukungan dari Pemerintah Kabupaten Aceh Timur terkait dengan pembangunan PLTA Tampur-I.

2. Tanggal 11 Oktober 2017, Bupati Aceh Timur baru menyampaikan dukungan terhadap pembangunan PLTA Tampur melalui Surat Bupati Aceh Timur No. 503/6457 Tahun 2017 perihal Dukungan Pembangunan PLTA Tampur - I dan Tampur II.
3. Tanggal 5 September 2018, M. Fahmi dari tim legal Yayasan HakA yang dalam perkara gugatan Objek Sengketa nantinya turut menjadi salah satu kuasa hukum Penggugat, muncul dalam pemberitaan media online www.mongabay.co.id berjudul "Masyarakat Aceh Desak Gubernur Aceh dan Menteri LHK Batalkan Proyek PLTA Tampur". Dalam penggalan beritanya, $\mathrm{M}$. Fahmi menyebutkan "Izin Pinjam Pakai Kawasan Hutan (IPPKH) yang digunakan PT KAMIRZU dinilai tidak sesuai dengan ketentuan peraturan perundang-undangan. Berdasarkan Peraturan Menteri Lingkungan Hidup dan Kehutanan Tentang Pedoman Pinjam Pakai Kawasan Hutan, IPPKH hanya bisa dikeluarkan oleh Menteri Lingkungan Hidup dan Kehutanan berdasarkan permohonan". "Sementara IPPKH untuk PLTA Tampur dikeluarkan oleh Gubernur Aceh dengan No. 522.51/DPMPTSP/1499/IPPKH/2017 tentang Izin Pinjam Pakai Kawasan Hutan guna pembangunan PLTA Tampur-I seluas \pm 4.407 hektare di Gayo Lues, Aceh Tamiang dan Aceh Timur. Izin dikeluarkan semasa Gubernur Zaini Abdullah pada 9 Juni 2017".

4. Tanggal 14 November 2018, WALHI Aceh menyampaikan kepada Gubernur Aceh cq. Dinas Penanaman Modal dan Pelayanan Terpadu Satu Pintu tentang Permohonan Informasi Perizinan 

atas Penerbitan Izin Pinjam Pakai Kawasan Hutan untuk Pembangunan PLTA Tampur

PT KAMIRZU melalui Surat No. 131/DE/WALHI-Aceh/XI/2018 Perihal Permohonan Dokumen.

5. Tanggal 5 Desember 2018, Pemerintah Aceh menerbitkan Surat Balasan Dinas Penanaman Modal dan Pelayanan Terpadu Satu PintuNo.540/DPMPTSP/3878/2018 Perihal Permintaan Dokumen PT KAMIRZU sebagai Surat Pengantar Balasan.

6. Tanggal 17 Desember 2018, Surat Pengantar Balasan tertanggal 5 Desember 2018 di atas beserta lampirannya disampaikan melalui email dari irhamvahlevi@ gmail.com kepada mrezamaulana.sh@gmail.com, yaitu dengan melampirkan dokumen sebagai berikut:

a. Surat Gubernur Aceh No. 671.21/BP2T/2523/2015 perihal Izin Prinsip Pembangunan Pembangkit Listrik Tenaga Air Tampur-I dan II;

b. Keputusan Gubernur Aceh No. 660/25/2017 tentang Kelayakan Lingkungan Hidup Rencana Pembangunan Pembangkit Listrik Tenaga Air Tampur I Provinsi Aceh dengan Pemrakarsa PT KAMIR$\mathrm{ZU}$;

c. Surat Keputusan Gubernur Aceh No. 522.51/DPMPTSP/1499/IPPKH/2017 tentang Pemberian Izin Pinjam Pakai Kawasan Hutan Dalam Rangka Pembangunan Pembangkit
Listrik Tenaga Air Tampur-I (443 MW) seluas $\pm 4.407 \mathrm{Ha}$ atas nama PT. KAMIRZU di Kabupaten Gayo Lues, Kabupaten Aceh Tamiang dan Kabupaten Aceh Timur Provinsi Aceh;

7. Tanggal 19 Desember 2018, Penggugat pertama kalinya mengetahui tentang telah diterbitkannya Objek Sengketa pada saat dibalasnya email oleh salah satu Pegawai DPMPTSP Aceh bernama Irham Vahlevi.

8. Tanggal 7 Januari 2019, Penggugat menyampaikan keberatannya terhadap Objek Sengketa kepada Gubernur Aceh melalui Surat No. 19/DE/WALHI Aceh/I/ 2019 Tanggal 07 Januari 2019 Perihal Mohon Pembatalan Objek Sengketa, namun hingga gugatan dilayangkan, Gubernur Aceh tidak menanggapi dan/ atau memberikan jawaban terkait keberatan yang disampaikan Penggugat.

9. Tanggal 29 Januari 2019, Gubernur Aceh menerbitkan perubahan atas Objek Sengketa, yaitu melalui Keputusan Gubernur Aceh No. 522.51/DPMPTSP/240/IPPKH/2019 Tanggal 29 Januari 2019 tentang Perubahan atas Keputusan Gubernur Aceh No. 522.51/ DPMPTSP/1499/IPPKH/2017 tentang Pemberian Izin Pinjam Pakai Kawasan Hutan Dalam Rangka Pembangunan Pembangkit Listrik Tenaga Air Tampur-I 
(443 MW) Seluas \pm 4.407 ha atas nama PT KAMIRZU di Kabupaten Gayo Lues, Kabupaten Aceh Tamiang, dan Kabupaten Aceh Timur Provinsi Aceh. Penerbitan perubahan atas Objek Sengketa adalah karena pada pokoknya terdapat penyesuaian 1) luasnya lahan yang telah ditetapkan dalam Izin Pinjam Pakai Kawasan Hutan Dalam Rangka Pembangunan Pembangkit Listrik Tenaga Air Tampur-I (443 MW) dari seluas \pm 4.407 ha menjadi \pm 4.130 ha; 2) kompensasi pembayaran PNBP penggunaan kawasan hutan; dan 3) melakukan penanaman dalam rangka rehabilitasi Daerah Aliran Sungai dan sarana penunjangnya pada Kawasan Hutan Lindung dan Kawasan Hutan Produksi

10. Tanggal 13 Februari 2019, Penggugat menyampaikan Banding Administratif kepada atasan Tergugat melalui Surat No. 31/DE/ WALHI Aceh/II/2019 Tanggal 13 Februari 2019 Perihal Banding Administratif Keberatan terhadap Objek Sengketa, namun sampai dengan diajukannya Gugatan a quo ke Pengadilan Tata Usaha Negara Banda Aceh, atasan Tergugat belum juga memberikan tanggapan terkait dengan Banding Administratif yang diajukan Penggugat.

11. Tanggal 11 Maret 2019, Penggugat mendaftarkan Gugatan Tata Usaha Negara in-casu di Kepani- teraan Pengadilan Tata Usaha Negara Banda Aceh.

12. Tanggal 23 April 2019, Majelis Hakim mengeluarkan Putusan Sela No. 7/G/LH/2019/PTUN. BNA/INTV yang mengabulkan permohonan PT Kamirzu untuk masuk sebagai pihak dalam perkara a quo dan mendudukkannya sebagai Tergugat II Intervensi;

13. Tanggal 7 Mei 2019, di hadapan persidangan Pihak Tergugat maupun Tergugat II Intervensi mengajukan jawabannya.

14. Tanggal 19 Agustus 2019, setelah melalui proses persidangan, Majelis Hakim PTUN Banda Aceh memutuskan bahwa Objek Sengketa tidak sah, dan mewajibkan Tergugat untuk mencabut Objek Sengketa.

\section{Catatan Pembelajaran}

\section{A. Terkait Tenggang Waktu Penga- juan}

Penggugat mendalilkan bahwa gugatan yang diajukan masih dalam tenggang waktu. Dasar hukum perhitungan tenggang waktu yang didalilkan oleh Penggugat adalah Pasal 55 UU No. 5 Tahun 1986 tentang Pengadilan Tata Usaha Negara (PTUN) sebagaimana telah diubah dengan UU No. 9 Tahun 2004 dan UU No. 51 Tahun 2009 juncto Pasal 5 ayat (2) Peraturan Mahkamah Agung No. 6 Tahun 2018 tentang Pedoman Penyelesaian Sengketa Administratif Pemerintahan Setelah Menempuh Upaya 
Administratif yang menentukan sebagai berikut.

Gugatan dapat diajukan hanya dalam tenggang waktu sembilan puluh hari terhitung sejak saat diterimanya atau diumumkannya Keputusan Badan atau Pejabat Tata Usaha Negara; Pihak ketiga yang tidak dituju oleh keputusan hasil tindak lanjut upaya administratif tenggang waktu pengajuan gugatan di pengadilan dihitung sejak yang bersangkutan pertama kali mengetahui keputusan tata usaha negara yang merugikan kepentingannya;

Karena Penggugat mendalilkan menerima Objek Sengketa tanggal 19 Desember 2018, kemudian mengajukan keberatan kepada Gubernur Aceh tanggal 07 Januari 2019, dan mengajukan Banding Administratif kepada atasan Gubernur Aceh sebagai Wakil Pemerintah di daerah dan/atau perpanjangtanganan pusat di daerah tanggal 13 Februari 2019, maka Gugatan Tata Usaha Negara yang didaftarkan Penggugat pada Kepaniteraan Pengadilan Tata Usaha Negara Banda Aceh pada 11 Maret 2019 dinyatakan masih dalam tenggang waktu 90 (sembilan puluh) hari.

Dalam Eksepsinya, Tergugat mendalilkan bahwa pengajuan gugatan telah melampaui Tenggang Waktu, karena Objek Sengketa terbit pada tanggal 9 Juni 2017, sedangkan Penggugat telah lama mengetahui adanya Objek Sengketa melalui salah satu kuasa hukumnya atas nama M. Fahmi yang juga merupakan tim legal Yayasan HakA sebagaimana pemberitaan media online www.mongabay.co.id tanggal 5 September 2018, sehingga pengajuan gugatan telah melampaui waktu 90 (sembilan puluh) hari.

Tentang tenggang waktu pengajuan gugatan tersebut, Majelis Hakim menganggap bahwa gugatan Penggugat masih masuk dalam tenggang waktu pengajuan gugatan dengan argumen sebagai berikut:

1. karena Penggugat bukan merupakan pihak yang dituju langsung oleh Objek Sengketa maka berlaku ketentuan penghitungan tenggang waktu pengajuan gugatan terhadap pihak ketiga sebagaimana ketentuan dalam pertimbangan di atas yakni 90 (sembilan puluh) hari sejak saat ia merasa kepentingannya dirugikan oleh Keputusan Tata Usaha Negara dan mengetahui adanya Keputusan Tata Usaha Negara tersebut;

2. terdapat ketentuan Pasal 75 sampai dengan Pasal 78 UU No. 30 Tahun 2014 tentang Administrasi Pemerintahan yang mengatur mengenai Upaya Administratif, hal mana dipertegas kembali dalam Pasal 5 ayat (1) Peraturan Mahkamah Agung No. 6 Tahun 2018 tentang Pedoman Penyelesaian Sengketa Administrasi Pe- 
merintahan Setelah Menempuh Upaya Administratif yang mengatur perhitungan tenggang waktu pengajuan gugatan di Pengadilan adalah 90 (sembilan puluh) hari sejak keputusan atas upaya administratif diterima atau diumumkan;

3. karena Penggugat merupakan pihak ketiga yang tidak dituju langsung oleh Objek Sengketa dan baru mengetahui adanya Objek Sengketa setidaknya pada tanggal 17 Desember 2018, dan telah melakukan Upaya Administratif Keberatan dengan surat tanggal 7 Januari 2019 serta tidak dijawab oleh Tergugat, maka tenggang waktu 90 (sembilan puluh) hari dihitung setelah seluruh Upaya Administratif dilakukan atau setidaknya sejak Upaya Administratif Keberatan telah lewat 10 (sepuluh) hari kerja sebagaimana ketentuan Pasal 77 ayat (4) UU No. 30 Tahun 2014;

4. pengajuan gugatan Penggugat masih dalam tenggang waktu dan terhadap eksepsi Tergugat yang pertama terkait pengajuan gugatan telah lewat waktu (kekedaluwarsa) beralasan hukum untuk dinyatakan tidak diterima.

Terhadap pertimbangan Majelis Hakim tersebut, Penulis menarik beberapa catatan pembelajaran sebagai berikut:

1. Majelis Hakim tidak menjadikan dalil Tergugat yang menyatakan bahwa Penggugat telah mengeta- hui adanya Objek Sengketa sejak lama sebagai dasar pertimbangan, melainkan menghitung tenggang waktu pengajuan gugatan sejak Penggugat merasa kepentingannya dirugikan oleh Objek Sengketa dan mengetahui adanya Objek Sengketa tersebut. Penulis sependapat dengan pertimbangan Majelis Hakim tersebut, karena Kuasa Hukum Penggugat dalam dalil Tergugat merupakan subjek hukum yang berbeda dengan Penggugat. Maka tenggang waktu harus diperhitungkan sejak Penggugat menerima Objek Sengketa yang karena berkedudukan sebagai pihak ketiga, diperoleh Penggugat melalui permohonan informasi.

2. Yang dimaksud dengan "keputusan tata usaha negara yang merugikan kepentingannya" dalam Pasal 5 ayat (2) Peraturan Mahkamah Agung No. 6 Tahun 2018 setidaknya dapat menimbulkan dua penafsiran, yaitu 1) Objek Sengketa; atau 2) keputusan hasil tindak lanjut upaya administratif. Jika dicermati dalam putusan, dalil yang diajukan Penggugat maupun Tergugat berdasarkan pada penafsiran "keputusan tata usaha negara" sebagai Objek Sengketa, sehingga perhitungan kedaluwarsa pengajuan gugatan dihitung sejak Penggugat mengetahui adanya Objek Sengketa. Namun dengan dasar hukum yang sama, dalam pertimbang- 
annya Majelis Hakim menafsirkan "keputusan tata usaha negara" sebagai keputusan hasil tindak lanjut upaya administratif, sehingga kemudian perhitungan kedaluwarsa dimulai setelah seluruh Upaya Administratif dilakukan, atau setidaknya sejak Upaya Administratif Keberatan telah lewat 10 (sepuluh) hari kerja.

3. Meskipun pertimbangan Majelis Hakim tentang tenggang waktu berdasarkan pada UU No. 30 Tahun 2014 tentang Administrasi Pemerintahan, yang mana menghitung kedaluwarsa pengajuan gugatan sejak Upaya Keberatan telah lewat 10 (sepuluh) hari kerja, Pasal 77 ayat (4) s.d. (7) UU No. 30 Tahun 2014 mengatur bahwa dalam hal Tergugat tidak menyelesaikan keberatan dalam jangka 10 (sepuluh) hari kerja, maka keberatan dianggap dikabulkan, sehingga dapat dimintakan penetapannya. Hal yang sama juga diatur untuk Upaya Administratif Banding dalam Pasal 78 ayat (4) s.d. (6) UU No. 30 Tahun 2014. Namun Penggugat tidak menggunakan Pasal 77 juncto Pasal 78 UU No. 30 Tahun 2014 tersebut sebagai dasar gugatan, dan Majelis Hakim tidak turut menyertakan mekanisme tersebut dalam pertimbangannya.

\section{B. Terkait Kelengkapan Objek Sengketa}

Tergugat maupun Tergugat II Intervensi mendalilkan bahwa objek gugatan Penggugat Tidak Lengkap (dan tidak sempurna), yaitu bahwa karena telah dilakukan revisi terhadap Objek Sengketa dengan terbitnya Surat Keputusan Gubernur Aceh No. 522.51/DPMPTSP/240/IPPKH/2019 tertanggal 29 Januari 2019 yang kemudian tidak dimasukkan oleh Penggugat sebagai objek sengketa.

Majelis Hakim dalam pertimbangannya kemudian menyatakan tidak menerima eksepsi Tergugat maupun Tergugat II Intervensi bahwa gugatan Penggugat kabur, tidak lengkap, dan tidak sempurna (obscuur libel), karena pada dasarnya Majelis Hakim berpendapat bahwa semua unsur yang harus ada dalam sebuah gugatan sebagaimana diatur dalam Pasal 56 ayat (1) UU No. 5 Tahun 1986 telah termuat dalam gugatan Penggugat. Adapun argumentasi Majelis Hakim adalah sebagai berikut:

1. untuk menyatakan suatu gugatan kabur adalah apakah gugatan Penggugat telah memenuhi ketentuan Pasal 56 ayat (1) UU No. 5 Tahun 1986 atau tidak (untuk kemudian didalilkan sebagai obscuur libel) harus melihat unsur yang termuat dalam suatu gugatan yakni: a. nama, kewarganegaraan, tempat tinggal, dan peker- 
jaan penggugat, atau kuasanya; b. nama jabatan, dan tempat kedudukan tergugat; c. dasar gugatan dan hal yang diminta untuk diputuskan oleh Pengadilan;

2. Majelis Hakim berpendapat semua unsur yang harus ada dalam sebuah gugatan sebagaimana ketentuan Pasal 56 ayat (1) UU No. 5 Tahun 1986, seluruhnya telah termuat dalam gugatan Penggugat;

3. Surat Keputusan Gubernur No. 522.51/ DPMPTSP / 240 / IPPKH/2019 tanggal 29 Januari 2019 tersebut tidak mengubah secara keseluruhan isi dari Objek Sengketa, namun hanya pada Diktum Kesatu dan Kedua saja. Hal tersebut juga diperkuat oleh pernyataan Tergugat II Intervensi pada Jawaban dalam Eksepsinya yang menyebutkan bahwa Objek Sengketa dan perubahannya merupakan satu kesatuan yang tidak dapat dipisahkan;

4. perubahan terhadap Objek Sengketa tersebut baru diketahui oleh Penggugat dan Majelis Hakim pada tahap persidangan dengan agenda Jawaban, dan secara fisik diperlihatkan pada Persidangan dengan agenda Pembuktian, sehingga tidak dimungkinkan untuk ditambahkan pada saat agenda Pemeriksaan Persiapan;

5. atas hal tersebut dan dihubungkan dengan fakta hukum yang ada, Majelis Hakim menarik per- ubahan terhadap Objek Sengketa sebagai Objek Sengketa II dan Objek Sengketa selanjutnya disebut sebagai Objek Sengketa I, kemudian secara bersama-sama Objek Sengketa I dan Objek Sengketa II selanjutnya disebut sebagai Objek Sengketa.

Terhadap pertimbangan Majelis Hakim tersebut, Penulis sependapat terhadap pertimbangan Majelis Hakim untuk terlebih dahulu menilai lengkap atau tidaknya gugatan berdasarkan unsurunsur gugatan yang diatur dalam Pasal 56 ayat (1) UU No. 5 Tahun 1986. Penulis juga sependapat atas pertimbangan Majelis Hakim yang juga melihat terlebih dahulu perubahan Objek Sengketa, yang kemudian dibuktikan tidak mengubah secara keseluruhan isi dari Objek Sengketa. Sebagai konsekuensi, dalam hal perubahan Objek Sengketa kemudian mengubah isi dari Objek Sengketa, sehingga terdapat perbedaan antar unsur-unsurnya, maka Penulis berpendapat bahwa adalah tepat dalil Tergugat dan Tergugat II Intervensi bahwa gugatan Penggugat kabur, tidak lengkap, dan tidak sempurna (obscuur libel) karena terdapat perbedaan pada dasar gugatannya.

\section{Terkait Kewenangan Penerbit- an Izin Pinjam Pakai Kawasan Hutan}

Dalam Pokok Perkara Gugatan, Penggugat menyatakan bahwa penerbitan Objek Sengketa bertentangan de- 

atas Penerbitan Izin Pinjam Pakai Kawasan Hutan untuk Pembangunan PLTA Tampur

ngan ketentuan peraturan perundangundangan yang berlaku karena Gubernur Aceh selaku penerbit Objek Sengketa melampaui wewenangnya untuk menerbitkan Objek Sengketa. Penggugat mendalilkan bahwa kewenangan pemberian Izin Pinjam Pakai Kawasan Hutan ("IPPKH") yang dilimpahkan dari Menteri kepada Gubernur sifatnya terbatas (limited authority) yaitu hanya bagi pembangunan fasilitas umum non komersial dengan luasan paling banyak 5 (lima) hektare sebagaimana diatur dalam Pasal 2 Perdirjen Planologi Kehutanan No. P.5/VII-PKH/2014 tentang Petunjuk Pelaksana Pemberian Izin Pinjam Pakai Kawasan Hutan yang dilimpahkan Menteri Kehutanan kepada Gubernur jo. Pasal 8 Permen LHK No. P.50/Menlhk/Setjen/ Kum.1/6/2016 tentang Pedoman Pinjam Pakai Kawasan Hutan. Atas peraturan tersebut, apabila dihubungkan dengan Objek Sengketa, Gubernur Aceh yang telah menerbitkan IPPKH kepada PT Kamirzu untuk pembangunan fasilitas umum non-komersial yaitu Pembangkit Listrik Tenaga Air (PLTA) dengan luas 4.407 Ha telah jelas-jelas bertentangan dengan ketentuan peraturan perundangundangan yang berlaku.

Terhadap gugatan tersebut, Tergugat dalam jawabannya membantah dalil Penggugat dengan menyatakan bahwa penerbitan Objek Sengketa merupakan kewenangan dari Tergugat. Tergugat mendasarkan argumennya pada Pasal
156 dan Pasal 16 5UU No. 11 Tahun 2006 tentang Pemerintah Aceh yang pada intinya mengatur bahwa Pemerintah Aceh mengelola sumber daya alam di Aceh, termasuk bidang kehutanan, dan berhak memberikan izin yang berkaitan dengan pengelolaan dan pengusahaan hutan sesuai dengan kewenangannya dan berdasarkan norma, standar, dan prosedur yang berlaku nasional. Sebagai ketentuan pelaksana dari kewenangan pengelolaan bidang kehutanan tersebut adalah Qanun Aceh No. 7 Tahun 2016 tentang Kehutanan Aceh, yang pada Pasal 54 diatur bahwa pemberian izin penggunaan Kawasan Hutan untuk kepentingan pembangunan di luar kegiatan kehutanan, termasuk kegiatan instalasi pembangkit, transmisi dan distribusi listrik, serta teknologi energi baru atau terbarukan, dilakukan melalui izin pinjam kawasan hutan yang dikeluarkan oleh Gubernur setelah mendapat rekomendasi dari Dinas dan dilaporkan kepada DPRA.

Adapun Tergugat II Intervensi juga turut memberikan jawaban terkait dengan kewenangan Gubernur Aceh sebagai Tergugat dalam menerbitkan Objek Sengketa. Tergugat II Intervensi mendalilkan bahwa IPPKH yang diatur dalam PP No. 24 Tahun 2010 tentang Penggunaan Kawasan Hutan terdapat 2 (dua) tipe, yaitu non-komersial dan komersial, sehingga bila dihubungkan dengan $\mathrm{Ob}$ jek Sengketa yang berdasarkan Pasal 4 ayat (2) huruf c PP No. 105 Tahun 2015 
maka IPPKH untuk instalasi pembangkit, transmisi dan distribusi listrik serta teknologi energi baru dan terbarukan tidak masuk dalam kategori sebagai penggunaan yang non-komersial, melainkan penggunaan komersial. Atas hal tersebut, Tergugat II Intervensi menyatakan bahwa dalil Penggugat tidak tepat dan keliru sehingga harus ditolak. Selain tipe IPPKH, Tergugat II Intervensi juga mendalilkan bahwa luas pemberian IPPKH yang terdapat dalam Objek Sengketa sangat kecil bila dibandingkan dengan luasan hutan yang ada di Provinsi Aceh, yaitu jika di persentasekan sebesar $0.17 \%$, dan tidak masuk dalam pengecualian atas pemberian izin pinjam pakai kawasan hutan dengan luas maksimal 10 \% sebagaimana ditentukan Pasal 10 ayat (8) Permen LHK No. P.50/Menlhk/Setjen/Kum.1/6/2016.

Pada akhirnya, Majelis Hakim berpendapat bahwa tindakan Tergugat dalam menerbitkan Objek Sengketa telah melewati batas kewenangan yang diberikan dari aspek cakupan bidang atau materi wewenang dengan menerbitkan izin diluar kewenangan yang diberikan. Walau demikian, pendapat Majelis Hakim tersebut disusun atas pertimbangan sendiri dan terlepas dari dalil Penggugat yang menyatakan bahwa Tergugat tidak berwenang menerbitkan Objek Sengketa sebagai IPPKH non komersial karena luasannya melampaui 5 (lima) ha, maupun jawaban dari Tergugat II Intervensi yang menyatakan bahwa IPPKH adalah untuk kegiatan komersial sehingga dalil Penggugat tidak tepat. Argumentasi Majelis Hakim adalah sebagai berikut:

1. Berdasarkan Pasal 156 ayat (1) dan ayat (3) UU No. 11 Tahun 2006 tentang Pemerintahan Aceh, Pemerintah Aceh mempunyai kewenangan untuk mengelola sumber daya alam di Aceh, termasuk bidang kehutanan. Pasal 165 ayat (3) huruf b dan ayat (5) UU No. 11 Tahun 2006 tentang Pemerintahan Aceh kemudian menyatakan bahwa Pemerintah Aceh sesuai dengan kewenangannya dan berdasarkan norma, standar, dan prosedur yang berlaku nasional berhak memberikan izin konversi kawasan hutan dengan ketentuan yang lebih lanjut diatur dengan Qanun.

2. Majelis Hakim kemudian mempertimbangkan Pasal 270 ayat (1) dan (2) UU No. 11 Tahun 2006 tentang Pemerintahan Aceh, yang mengatur bahwa kewenangan Pemerintah yang bersifat nasional dan pelaksanaan UU ini yang menyangkut kewenangan Pemerintah diatur dengan peraturan perundang-undangan, sementara kewenangan Pemerintah Aceh tentang pelaksanaan UU ini diatur dengan Qanun.

3. Atas dasar Pasal 270 UU No. 11 Tahun 2006 tentang Pemerintahan Aceh tersebut diterbitkan PP No. 3 Tahun 2015 tentang Kewe- 
nangan Pemerintah yang Bersifat Nasional di Aceh, dan Qanun Aceh No. 7 Tahun 2016 tentang Kehutanan Aceh.

4. Dalam Pasal 4 huruf bb jo. Pasal 6 PP No. 3 Tahun 2015 tentang Kewenangan Pemerintah yang Bersifat Nasional di Aceh, Pemerintah (pusat) mempunyai kewenangan untuk mengatur dan mengurus urusan pemerintahan di Aceh yang bersifat nasional, salah satunya adalah kehutanan. Rincian kewenangan Pemerintah tersebut kemudian dicantumkan dalam Lampiran PP No. 3 Tahun 2015 Sub Judul BB. Bidang Kehutanan Sub Bidang Penatagunaan Kawasan Hutan, yaitu penetapan kebijakan, norma, standar dan prosedur penatagunaan kawasan hutan, dalam pelaksanaan penetapan fungsi, perubahan hak dari lahan milik menjadi kawasan hutan, perizinan penggunaan kawasan hutan. Maka Majelis Hakim menimbang bahwa terhadap perizinan penggunaan kawasan hutan, merupakan wewenang dari pemerintah pusat untuk menetapkan kebijakan, norma, standar, dan prosedurnya.

5. Bahwa kemudian berdasarkan Pasal 4, Pasal 6 ayat (1), dan Pasal 7 PP No. 105 Tahun 2015, penggunaan kawasan hutan untuk kepentingan pembangunan di luar kegiatan kehutanan hanya dapat dilakukan untuk kegiatan yang mempunyai tujuan strategis yang tidak dapat dielakkan, salah satunya adalah instalasi pembangkit, transisi, dan distribusi listrik, serta teknologi energi baru dan terbarukan; dan waduk, bendungan, bendung, irigrasi, saluran air minum, saluran pembuangan air dan sanitasi, dan bangunan perairan lainnya. Penggunaan kawasan hutan untuk kepentingan tersebut dilakukan berdasarkan IPPKH yang diberikan oleh Menteri berdasar permohonan. Adapun Menteri dapat melimpahkan wewenang pemberian IPPKH dengan luasan tertentu kepada gubernur untuk pembangunan fasilitas umum yang bersifat non komersial.

6. Dengan kemudian menimbang Pasal 8 ayat (1) dan ayat (2) Permen LHK No. P.50/Menlhk/Setjen/Kum.1/6/2016 serta peraturan penggantinya Permen LHK No. P.27/Menlhk/Setjen/ Kum.1/7/2018 tentang Pedoman Pinjam pakai Kawasan Hutan, serta fakta hukum dalam proses persidangan, Majelis Hakim berpendapat bahwa yang berwenang dalam menerbitkan Objek Sengketa seharusnya adalah Menteri Lingkungan Hidup dan Kehutanan, dikarenakan luas areal dalam Objek Sengketa melebihi kewenangan yang dilimpahkan kepada Gubernur.

7. Sementara itu, terkait kewenangan Gubernur yang tertuang da- 
lam Qanun Aceh No. 7 Tahun 2016 tentang Kehutanan Aceh, Majelis Hakim mempertimbangkan bahwa pada Bagian Umum Penjelasan atas Qanun Aceh No. 7 Tahun 2016 tentang Kehutanan Aceh, terdapat penjelasan bahwa selain urusan pemerintahan yang menjadi kewenangan Pemerintah yang bersifat nasional di Aceh sebagaimana diatur dalam PP No. 3 Tahun 2015, selebihnya adalah urusan Pemerintah Aceh. Maka Qanun merupakan aturan pelaksanaan dari urusan pemerintahan di bidang Kehutanan yang menjadi kewenangan Pemerintah Aceh, dan atas hal tersebut, Majelis Hakim berpendapat bahwa kewenangan Gubernur Aceh selaku Tergugat dalam menerbitkan Izin Penggunaan Kawasan Hutan hanya terbatas pada pelimpahan wewenang yang diberikan kepada Gubernur, yaitu fasilitas umum yang bersifat non komersial dengan luas paling banyak 5 (lima) hektare.

Selain pertimbangan terkait kewenangan Tergugat untuk menerbitkan IPPKH, Majelis Hakim juga memberikan catatan terkait pemberian IPPKH pada Kawasan Ekosistem Leuser. Sebagaimana turut didalilkan oleh Penggugat, Pasal 150 UU No. 11 Tahun 2006 mengatur bahwa Pemerintah menugaskan Pemerintah Aceh untuk melakukan pengelolaan kawasan ekosistem Leuser di wila- yah Aceh; dan Pemerintah, Pemerintah Aceh, dan pemerintah kabupaten/kota dilarang mengeluarkan izin pengusahaan hutan dalam kawasan ekosistem Leuser. Dalam persidangan diketahui sebagai berikut:

1. fakta bahwa Area Reservoir (genangan) terletak pada area Hutan Lindung, Hutan Produksi dan Areal Penggunaan Lain (APL), sedangkan Work Area Plan sepenuhnya berada pada Hutan Lindung, dan akses jalan baru terletak pada Hutan Lindung dan Hutan Produksi, dan

2. dari hasil Pemeriksaan Setempat yang dilakukan oleh Majelis Hakim, diketahui bahwa bendungan direncanakan akan dibangun pada area Hutan Lindung yang terletak dalam Kawasan Ekosistem Leuser, sedangkan waduk atau area genangan sebagian masuk dalam Hutan Lindung Kawasan Ekosistem Leuser dan sebagian lagi akan menggenangi Desa Lesten yang merupakan Areal Penggunaan Lain (APL).

Majelis Hakim kemudian menyatakan bahwa penerbitan IPPKH harus memperhatikan pula ketentuan dalam Pasal 150 UU No. 11 Tahun 2006 tentang Pemerintahan Aceh yang mengamanatkan kepada Pemerintah, Pemerintah Aceh, dan Pemerintah Kabupaten/Kota untuk tidak mengeluarkan izin pengusahaan hutan dalam Kawasan Ekosistem Leuser. 

atas Penerbitan Izin Pinjam Pakai Kawasan Hutan untuk Pembangunan PLTA Tampur

Terhadap pertimbangan Majelis Hakim tersebut, Penulis berpendapat bahwa Majelis Hakim telah menyusun alur pertimbangan dengan logis dan baik, yaitu dengan catatan pembelajaran sebagai berikut:

1. Penulis sependapat atas argumentasi Majelis Hakim terkait pembagian kewenangan bidang kehutanan antara Pemerintah Pusat dengan Pemerintah Aceh, yaitu bahwa meskipun Pemerintah Aceh memiliki kewenangan di bidang kehutanan, penetapan regulasi (kebijakan, norma, standar dan prosedur penatagunaan kawasan hutan) dalam pelaksanaan penetapan fungsi, perubahan hak dari lahan milik menjadi kawasan hutan, dan perizinan penggunaan kawasan hutan tetap menjadi kewenangan Pemerintah Pusat. ${ }^{8}$

2. Atas hal tersebut, Majelis Hakim telah menyusun argumentasi dengan tepat dengan menarik kesimpulan bahwa tindakan Tergugat dalam menerbitkan Objek Sengketa telah melewati batas kewenangan yang diberikan berdasarkan peraturan perundang-undangan, yang terbatas untuk 1) fasilitas umum yang bersifat non komersial; dan 2) dengan luas paling banyak 5 (lima) hektare. ${ }^{9}$ Terkait sifat peruntukan PLTA Tampur sebagai fasilitas umum yang bersifat komersial juga telah didalilkan oleh Tergugat II Intervensi dalam menjawab dalil Pokok Perkara yang diajukan Penggugat yang menyatakan Objek Sengketa sebagai IPPKH non komersial dengan luasannya melampaui 5 (lima) hektare.

3. dalam proses persidangan, Majelis Hakim PTUN melaksanakan kekuasaan kehakimannya melalui Pemeriksaan Setempat pada lokasi Objek Sengketa tanggal 1 Agustus 2019. Praktik Pemeriksaan Setempat jarang ditemui terutama dalam peradilan tata usaha negara, yang lebih umum terpaku pada penerbitan Objek Sengketa secara formal, serta pembuktian materiil yang terbatas pada yang didalilkan para pihak bersengketa dalam ruang persidangan. Lokasi Objek Sengketa dapat dibuktikan melalui Peta Pengesahan Batas Kawasan Ekosistem yang dilampirkan oleh Penggugat, dan pembuktian mengenai pelaksanaan kewajiban Tergugat II Intervensi terhadap Masyarakat Desa Lesten sebagai-

${ }^{8}$ Indonesia, Undang-Undang tentang Pemerintahan Aceh, UU No. 11 Tahun 2006 Pasal 270 ayat (1) dan (2) jo. Pasal 4 huruf bb jo. Peraturan Pemerintah tentang Kewenangan Pemerintah yang Bersifat Nasional di Aceh, PP No. 3 Tahun 2015 Pasal 6.

${ }^{9}$ Indonesia, Peraturan Pemerintah tentang Penggunaan Kawasan Hutan, PP No. 105 Tahun 2015 Pasal 4, Pasal 6 ayat (1), dan Pasal 7 jo. Peraturan Menteri Lingkungan Hidup dan Kehutanan tentang Pedoman Pinjam Pakai Kawasan Hutan, Permen LHK No. P.50/Menlhk/Setjen/Kum.1/6/2016 Pasal 8 ayat (1) dan ayat (2). 
mana diperdebatkan dalam Pokok Perkara umumnya terbatas pada pembuktian yang didalilkan para pihak pada proses persidangan. Namun dengan pelaksanaan Pemeriksaan Setempat, Majelis Hakim menyiratkan perhatian terhadap subjek yang diatur oleh Objek Sengketa, yaitu masyarakat Desa Lesten dan Kawasan Ekosistem Leuser.

4. Pada akhirnya, perhatian Majelis Hakim PTUN Banda Aceh terhadap Kawasan Ekosistem Leuser tampak dari pertimbangan putusan yang menggarisbawahi kembali Pasal 150 UU No. 11 Tahun 2006 tentang Pemerintahan Aceh yang pada intinya mengamanatkan Tergugat untuk tidak mengeluarkan izin pengusahaan hutan dalam Kawasan Ekosistem Leuser.

\section{Catatan terhadap Perizinan Pem- bangunan PLTA Tampur dari Perspektif Ketenagalistrikan}

Selain kewenangan penerbitan IPP$\mathrm{KH}$ yang melebihi kewenangan Tergugat, pada dasarnya terdapat beberapa dalil lain yang diajukan Penggugat sebagai Pokok Perkara untuk menggugat agar Objek Sengketa dinyatakan tidak sah dan dicabut demi hukum, yaitu:

1. PT Karmizu (yang kemudian menjadi Tergugat II Intervensi) belum melaksanakan kewajiban hukumnya untuk menyelesaikan tata batas areal dan menyelesai- kan relokasi Desa Lesten dalam jangka waktu 1 (satu) tahun setelah IPPKH terbit, sehingga sebagaimana diatur dalam Objek Sengketa, IPPKH menjadi batal dan dinyatakan tidak berlaku;

2. Objek Sengketa cacat yuridis, karena dalam Diktumnya juga disebutkan bahwa Objek Sengketa diterbitkan sebagai Izin Pemanfaatan Kayu dan Izin Pemasukan dan Penggunaan Peralatan dalam satu keputusan;

3. Tentang tidak adanya rekomendasi Bupati Kabupaten Aceh Timur, meskipun Objek Sengketa diterbitkan untuk 3 (tiga) Kabupaten termasuk Kabupaten Aceh Timur. Rekomendasi Bupati Kabupaten Aceh Timur baru diberikan setelah Objek Sengketa terbit;

4. Objek Sengketa diterbitkan berdasarkan Rekomendasi dari Kepala Dinas Lingkungan Hidup dan Kehutanan Aceh yang juga diterbitkan pada tanggal yang sama, yaitu 9 Juni 2017, sementara menurut nalar pikir rasional tidak mungkin diterbitkan pada hari dan tanggal yang sama;

5. Areal yang diperuntukkan dalam Objek Sengketa berada dalam Kawasan Zona Patahan Aktif;

6. Potensial dampak akibat diterbitkannya Objek Sengketa bagi lingkungan hidup Kawasan Ekosistem Leuser beserta keanekaragaman hayati di dalamnya. 
Analisis Putusan PTUN NO. 7/G/LH/2019/PTUN.BNA antara Walhi Melawan Gubernur Aceh atas Penerbitan Izin Pinjam Pakai Kawasan Hutan untuk Pembangunan PLTA Tampur

Namun, karena Majelis Hakim mempertimbangkan bahwa Tergugat tidak berwenang dalam menerbitkan Objek Sengketa, maka terhadap prosedur dan substansi penerbitan Objek Sengketa menjadi tidak relevan untuk dipertimbangkan lagi.

Selain pembuktian atas Pokok Perkara yang terjadi selama proses persidangan dan dengan memperhatikan proses penerbitan Objek Sengketa yang terkesan cepat (melewati terbitnya Rekomendasi Bupati Kabupaten Aceh Timur dan diterbitkan pada hari yang sama dengan Rekomendasi Kepala Dinas Lingkungan Hidup dan Kehutanan Aceh), menarik untuk melihat urgensi terbitnya Objek Sengketa sebagai bagian dari perizinan pembangunan PLTA Tampur dari perspektif perencanaan pembangunan infrastruktur ketenagalistrikan.

Berikut beberapa catatan terkait IPPKH yang diterbitkan bagi PT Karmi- zu untuk melaksanakan pembangunan PLTA Tampur. ${ }^{10}$ Pertama, dari proses penyediaan jasa ketenagalistrikan, IPPKH beserta perizinan terkait yang dibutuhkan untuk pembangunan PLTA seharusnya baru dapat diperoleh setelah perusahaan penyedia tenaga listrik memiliki Izin Usaha Pembangkit Tenaga Listrik Sementara (IUPTLS), serta Power Purchase Agreement (PPA) antara PT PLN (Persero) dengan perusahaan penyedia tenaga listrik tersebut, dalam hal ini PT Karmizu. Ini untuk memastikan bahwa perusahaan penyedia tenaga listrik akan betul beroperasi, sehingga dengan demikian memastikan peruntukan perizinan (termasuk izin pinjam pakai kawasan) yang diberikan adalah untuk pembangunan instalasi pembangkit tenaga listrik. Secara umum, proses pembangunan pembangkit tenaga listrik dapat dibagi menjadi beberapa tahap, yang dijelaskan melalui tabel berikut: ${ }^{11}$

\section{Tabel 2. Proses Pembangunan Pembangkit Tenaga Listrik}

\begin{tabular}{l|l|l|l|l|l} 
Perencanaan & Pengadaan & $\begin{array}{c}\text { Power Pur- } \\
\text { chase Agree- } \\
\text { ment - Periz- } \\
\text { inan }\end{array}$ & $\begin{array}{c}\text { Pengurusan } \\
\text { Perizinan }\end{array}$ & Pendanaan & $\begin{array}{c}\text { Konstruksi - } \\
\text { Operasi }\end{array}$ \\
\hline $\begin{array}{l}\text { Feasibility Stu- } \\
d y, \text { yaitu untuk } \\
\text { memeriksa } \\
\text { kebutuhan } \\
\text { pembangunan }\end{array}$ & $\begin{array}{l}\text { Proses penga- } \\
\text { daan ditandai } \\
\text { dengan pe- } \\
\text { nyelenggaraan } \\
\text { pemilihan }\end{array}$ & $\begin{array}{l}\text { PPA untuk } \\
\text { memastikan } \\
\text { bahwa listrik } \\
\text { yang dihasil- } \\
\text { kan akan di- }\end{array}$ & $\begin{array}{l}\text { Setelah PPA } \\
\text { ditandata- } \\
\text { ngani, perusa- } \\
\text { haan pengem- } \\
\text { bang akan }\end{array}$ & $\begin{array}{l}\text { Proses pen- } \\
\text { carian lender } \\
\text { sampai financi- } \\
\text { al closing. }\end{array}$ & $\begin{array}{l}\text { Setelah per- } \\
\text { izinan yang } \\
\text { dibutuhkan } \\
\text { terpenuhi, } \\
\text { maka perusa- }\end{array}$ \\
\hline
\end{tabular}

${ }^{10}$ Hasil wawancara dengan Grita Anindarini, S.H., LL.M., peneliti bidang Energi pada Yayasan Indonesian Center for Environmental Law (ICEL), di Kantor ICEL, Jakarta Selatan, tanggal 30 Oktober 2019.

${ }^{11}$ Ibid. 


\begin{tabular}{|c|c|c|c|c|}
\hline $\begin{array}{l}\text { instalasi } \\
\text { pembangkit } \\
\text { tenaga listrik } \\
\text { berdasarkan } \\
\text { kebutuhan } \\
\text { listrik, jaring- } \\
\text { an, potensi } \\
\text { yang ada, serta } \\
\text { kemana saja } \\
\text { tenaga listrik } \\
\text { yang diha- } \\
\text { silkan akan } \\
\text { dialirkan (ba- } \\
\text { lancing supply } \\
\text { and demand). }\end{array}$ & $\begin{array}{l}\text { langsung oleh } \\
\text { PT. PLN (Per- } \\
\text { sero), Untuk } \\
\text { kemudian di- } \\
\text { ambil } 1 \text { (satu) } \\
\text { pengembang } \\
\text { yang akan ber- } \\
\text { tindak sebagai } \\
\text { operator atau } \\
\text { Independent } \\
\text { Power Producer }\end{array}$ & $\begin{array}{l}\text { beli oleh PLN. } \\
\text { Pada proses } \\
\text { ini, PPA ter- } \\
\text { sebut akan di- } \\
\text { tandatangani } \\
\text { oleh kedua } \\
\text { belah pihak } \\
\text { dan paling } \\
\text { sedikit memu- } \\
\text { at: a) jangka } \\
\text { waktu; b) hak } \\
\text { dan kewajiban } \\
\text { penjual dan } \\
\text { pembeli; c) } \\
\text { alokasi risiko; } \\
\text { d) jaminan } \\
\text { pelaksanaan } \\
\text { proyek; e) } \\
\text { komisioning } \\
\text { dan COD; } \\
\text { f) pasokan } \\
\text { bahan bakar; } \\
\text { g) transaksi; h) } \\
\text { pengendalian } \\
\text { operasi sistem; } \\
\text { i) penalti ter- } \\
\text { hadap kinerja } \\
\text { pembangkit; j_- } \\
\text { pengakhiran } \\
\text { perjanjian; k_ } \\
\text { pengalihan } \\
\text { hak; l) persya- } \\
\text { ratan penyesu- } \\
\text { aian harga; m) } \\
\text { penyelesaian } \\
\text { perselisihan; } \\
\text { dan n) keada- } \\
\text { an kahar (Pa- } \\
\text { sal } 3 \text { Permen } \\
\text { ESDM No. 10 } \\
\text { Tahun 2017) }\end{array}$ & $\begin{array}{l}\text { mulai mengu- } \\
\text { rus perizinan } \\
\text { yang dibu- } \\
\text { tuhkan untuk } \\
\text { pembangunan } \\
\text { pembangkit. } \\
\text { Dalam proses } \\
\text { ini, pengem- } \\
\text { bang mengu- } \\
\text { rus izin-izin } \\
\text { seperti Izin } \\
\text { Lingkungan } \\
\text { ("IL”) sampai } \\
\text { dengan Izin } \\
\text { Usaha Penye- } \\
\text { diaan Tenaga } \\
\text { Listrik (IUP- } \\
\text { TL). } \\
\text { Untuk pengu- } \\
\text { rusan izin } \\
\text { yang dibutuh- } \\
\text { kan tersebut, } \\
\text { ESDM (seka- } \\
\text { rang dialihkan } \\
\text { kepada OSS) } \\
\text { akan mener- } \\
\text { bitkan IUPTLS } \\
\text { sebagai bentuk } \\
\text { kepastian akan } \\
\text { dilaksanakan- } \\
\text { nya proyek } \\
\text { yang dibutuh- } \\
\text { kan perusa- } \\
\text { haan untuk } \\
\text { mengurus } \\
\text { perizinan yang } \\
\text { lain sampai } \\
\text { dengan men- } \\
\text { cari pendana- } \\
\text { an. }\end{array}$ & $\begin{array}{l}\text { haan penyedia } \\
\text { tenaga listrik } \\
\text { akan memulai } \\
\text { proses kon- } \\
\text { struksi hinga } \\
\text { instalasi pem- } \\
\text { bangkit tenaga } \\
\text { listrik selesai } \\
\text { dibangun dan } \\
\text { siap operasi. }\end{array}$ \\
\hline
\end{tabular}

Dalam putusan tidak disebutkan apakah PT Karmizu telah mendapatkan IUPTLS sebagai dasar penerbitan IPPKH. Selain itu, tidak ditemukan juga informasi apakah PT Karmizu telah menandatangani PPA dengan PT PLN (Persero). Penerbitan IPPKH tanpa adanya
IUPTLS menimbulkan risiko bahwa IPPKH yang diterbitkan tidak digunakan untuk pembangunan instalasi pembangkit tenaga listrik.

Kedua, pembangunan PLTA Tampur dalam Rencana Usaha Penyediaan Tenaga Listrik Tahun 2019 - 2028 (RUPTL) 

atas Penerbitan Izin Pinjam Pakai Kawasan Hutan untuk Pembangunan PLTA Tampur

yang diterbitkan PT PLN (Persero) belum dapat dipastikan kejelasannya. Dari RUPTL PT. PLN (Persero) 2019-2028, terlihat bahwa status PLTA Tampur masih dalam tahap potensi, yang sebenarnya dapat terlihat diarahkan untuk mengisi Hidro Sumatera Tersebar, yang akan ditargetkan beroperasi pada 2025. ${ }^{12}$

Adapun berdasarkan RUPTL tersebut, status proyek ini masih dalam tahap perencanaan, yang mana seharusnya masih dilakukan feasibility study untuk melihat kebutuhan sistem, sehingga masih terbuka kemungkinan untuk lokasi pembangunan berpindah apabila dari hasil feasibility study tersebut ternyata terdapat sistem yang lain yang membutuhkan. Jika dibandingkan antara proses pembangunan pembangkit tenaga listrik dalam tabel di atas dengan posisi perencanaan PLTA Tampur yang ada di dalam RUPTL sekarang, patut dipertanyakan dasar pertimbangan IPPKH telah diberikan. Hal ini dikarenakan secara sistem, masih dimungkinkan pembangunan dipindahkan pada lokasi lain apabila dibutuhkan. Berkaca pada proses pembangunan PLTA Tampur yang belum jelas, perlu ada pertimbangan atas dampak diterbitkannya IPPKH saat kebutuhan sistem kemudian menyatakan bahwa tidak diperlukan pengembangan PLTA di wilayah tersebut. Bagaimana nasib dan pertanggungjawaban terhadap kawasan hutan tersebut hingga IPPKH terkait dibatalkan karena tidak sesuai dengan alasan penerbitannya?

Dari pernyataan diatas, terdapat dua kemungkinan kejanggalan terhadap pembangunan PLTA Tampur. Pertama kemungkinan penerbitan IPPKH untuk PLTA Tampur seakan-akan tergesa-gesa, dan tidak sesuai prosedur. Atau kedua, kemungkinan RUPTL PT. PLN (Persero) tidak memberikan informasi yang akurat terkait dengan perencanaan pengembangan pembangkit tenaga listrik. Pasalnya, adanya IPPKH yang telah terbit tidak sesuai dengan alur perencanaan ketenagalistrikan dan seharusnya peran Pemerintah Pusat, dalam hal ini adalah Direktorat Jenderal Ketenagalistrikan Kementerian ESDM, sebagai pihak yang berwenang untuk melakukan pengawasan terhadap penyusunan RUPTL untuk dapat menemukan kejanggalan ini dan menindaklanjutinya.

\section{Penutup}

Dari hasil pengulasan terhadap $\mathrm{Pu}$ tusan PTUN NO. 7/G/LH/2019/PTUN. BNA tanggal 19 Agustus 2019 beserta pertimbangan Majelis Hakim yang terdapat di dalamnya, dapat ditarik kesimpulan sebagai berikut:

\footnotetext{
${ }^{12}$ RUPTL PT. PLN (Persero) 2019-2028, hlm. A7-A8.
} 
1. Majelis Hakim melaksanakan kekuasaan kehakimannya dengan menarik alur argumentasi sendiri, tanpa keluar dari dalil Penggugat, Tergugat, dan Tergugat II Intervensi. Misalnya penafsiran Majelis Hakim atas "keputusan tata usaha negara" dalam Pasal 5 ayat (2) Peraturan Mahkamah Agung No. 6 Tahun 2018 sebagai keputusan hasil tindak lanjut upaya administratif.

2. Dalam beberapa pertimbangan, Majelis Hakim bahkan menggunakan argumentasi Tergugat dan Tergugat II Intervensi untuk memperkuat dalil Penggugat. Hal ini tampak pada saat:

a. Majelis Hakim menarik Objek Sengketa beserta perubahannya sebagai satu kesatuan untuk menyatakan bahwa gugatan telah memenuhi Pasal 56 ayat (1) UU No. 5 Tahun 1986 ,

b. Majelis Hakim menyusun pertimbangan bahwa IPPKH dalam Objek Sengketa adalah IPPKH untuk kepentingan komersial sebagaimana didalilkan oleh Tergugat II Intervensi, sehingga diluar kewenangan Tergugat untuk menerbitkannya.

3. Pelaksanaan kekuasaan kehakiman Majelis Hakim pada Pemeriksaan Setempat yang dilakukan Majelis Hakim untuk memeriksa lokasi yang diatur oleh Objek Sengketa dan masyarakat Desa Lesten, hal yang tidak umum ditemui pada peradilan tata usaha negara.

4. Selain tampak dari pelaksanaan Pemeriksaan Setempat, perhatian Majelis Hakim terhadap lokasi Objek Sengketa sebagai Kawasan Ekosistem Leuser cukup menarik. Hal ini dikarenakan Majelis Hakim tidak semata-mata mempertimbangkan persoalan kewenangan penerbitan izin namun juga memperhatikan kewajiban Gubernur Aceh untuk menjaga Kawasan Ekosistem Leuser sebagaimana diamanatkan dalam Pasal 150 UU No. 11 Tahun 2006 tentang Pemerintahan Aceh, setelah menyatakan Tergugat tidak berwenang menerbitkan $\mathrm{Ob}$ jek Sengketa.

5. Dalam hal terdapat sengketa tata usaha negara terkait perizinan instalasi pembangkit tenaga listrik, baik untuk melihat Objek Sengketa dan mempelajari perkara dari perspektif ketenagalistrikan, yaitu untuk mengetahui urgensi izin yang menjadi Objek Sengketa diterbitkan sebagai bahan penyusunan dalil dan juga pertimbangan dalam Putusan. 